\title{
Reasons of Emily's Tragic Fate in A Rose for Emily
}

\author{
Bei-bei Ye \\ School of Foreign Studies, Yangtze University, Jinzhou, Hubei Province, China
}

\begin{abstract}
A Rose for Emily is one of Faulkner's most famous short stories. The sophisticated plot and vivid characterization design made the image of Emily very popular. Many scholars resolve this novel from different aspects. This article mainly discusses the reasons of Emily's tragedy. These reasons generally can be divided into two categories, one is the environmental factor, and the other is Emily herself. This article will describe these two reasons in details to make people think about whether Emily is really the victim or it is a destiny.

Index Terms - A Rose for Emily, tragic, fate, reason
\end{abstract}

\section{Emily's Living Environments}

\section{A. Complex and Objective Social and Historical Environments}

During the particular time of transition from the old to the new in the United States, Emily's tragic fate has its deep historical and cultural roots. Emily Gleason and her father, as the last descendant of the Gleason family, were the representatives stick to the Southern Complex. They dared not face the reality, only with the Southern aristocratic former glory to numb themselves, to defend their noble image.

Under the "lady's style" constraints, women must suppress their nature, comply with the doctrine of women, and comply with the so-called matched for marriage thoughts. This is the most fundamental social causes of Emily and "Yankee" tragic love. And it is such traditional ideology, and concept that create Miss Emily's twisted personality and metamorphosis inner world.

\section{B. Conventional Patriarchy}

Another important part of the traditional culture of the South is patriarchy. It is in such an oppressive regime that women basically shape themselves according to the masculine aesthetic requirements. Emily's father is a strong defender of the feudal traditional culture. His bondage and repression to Emily is responsible for her distortions of her personality and her tragic fate. Emily was mercilessly trapped in the dilapidated house which symbolized the Southern aristocracy power. Loss of freedom, no matter how Emily struggled, she could not escape. The father had always dominated the reality and the spiritual world of Emily. She did not realize that her father's stifling her freedom and imprisoning her ideas was the fuse of her tragic fate." Bing trapped in the dilapidated old house which once was symbol of the southern prestige and dignity, Miss Emily's rose-like heart which longed for romantic life gradually withered.

\section{Over Concern and Picky Eyes from People around Her}

Emily finally inherited the small building as her father's wished, but also inherited the identity of the declining aristocracy. Although the society itself went forward with irresistible force, in the town, the people's ideology is still stagnant and ignorant. After his father died, this ignorance was gradually transformed into the discussion and criticism to Emily. Firstly, to the town residents, her father's death is actually the downfall of Greer Johnson family's. So they could talk about Emily's life. Secondly, the town residents began to concern and discuss Emily's marriage. Perhaps Emily figured out that she needed to lead a normal life. Since it was not the aristocracy, she had the right to have her own happiness.

It was at this time the, Yankees Homer - Barron walked into her life. Residents of the town seemed to feel sorry for the control of Emily's past by her father. So, when she and Homer were together, they were even some happy for her. However, the talk began to spread again. But this time, it seemed that the women did not gloat but were ill picky. It looked more like a reprisal to the privileges that Greer family enjoyed. This moment was then. Nobility was no longer a symbol of status but a symbol for people in the town to accuse Emily. The slanderous gossip could not stop Miss Emily to find her own happiness. However, residents of the town didn't want to see Emily being happy. Because it seemed that Emily would once again become a nobleman. The tragedy still happened, the flaws of Homer finally let vulnerable Emily insulated with the entire world. She became a demon of killing her husband.

\section{The Reasons of Emily Herself}

\section{A. The Failure of Love}

Emily was ready to get married. Even the priest's wife wrote letters to Emily's relatives living in Alabama. It cannot alter her decision to marry to Homer. But Homer did not want to get married. As he said it: he liked men. Perhaps this was his personal preference, but he did not let Emily know the truth. To Emily, who devoted all her feelings to another, the fate of her just opened a big joke. She put down her pride being spotlight on the town with Homer. She took the initiative to prepare the wedding for Homer but Homer refused. Unluckily, Emily chose an extreme way to poison Homer to death.

After poisoning Homer to death, Emily vented the emotions of hatred upon the town residents. She thought that women were so picky that she lost her face and this was also an important reason why she poisoned Homer. As Emily was too empty in mind and could not get solace. She poisoned Homer to have one man accompany her. Unfortunately, she got him at the same time she lost him forever, or at least she had been spiritually dead at the moment she poisoned him. Her heart was always filled with sorrow, sadness and helplessness. 


\section{B. Social Observer}

Emily's fate is a solid personal tragedy, but it also reflects the negative side of society. Emily is a victim of her age. In Emily's whole life, Emily never seemed to blend with the world around her. In the early age, the reason was that her father protected her. And in the later, the reason was that the love she had experienced.

Emily spent her whole lifetime in the empty house. From the beginning to the end, Emily had never been affected by the society, regardless of the changing times, or the flowing goofy language from the town residents. Although in Emily's age, the society was developing, everything was advancing and was in progress. But all these did not affect Emily. Social changes did not affect any of the work of Emily, and any habits. All the time, she stood in the outer edge of society, and always had nothing to do with this community. She was just a bystander.

The sad thing was that, Emily herself had been forgotten by the society. After Emily poisoned Homer, Homer's body exuded an unpleasant taste. In the eyes of the residents of the town, it was such a disgusting taste that produced a relationship between the society and superior alternative Greer Johnson family. Ironically, the author's tone raised a strong penetration of sorrow. On the other hand, she was forgotten by the society while she could not completely be divorced from the social fetters and shackles. Imperceptibly, she still needed to withstand the harsh social exclusion. Emily can refuse to pay taxes, but she cannot reject the inherent orange stems from the community.

\section{Emily's Character}

Miss Emily was born in a time of the southern plantation economy. She had a noble birth and lived in a family where father was the controller. Such a noble lady's identity of a white people decided that she must be a gentle woman, obey the traditional moral values. When her father was alive she had no right to decide her own destiny, and had no chance to get in touch with the young man. She had been got ride off the right of a woman longing for love. She lived all day at home which was like a cage, her thoughts and desires are completely confined. In this repressive society, Emily was longing for love, but she could not go against his father - the ruler of the house. When his father died, Emily met Homer who took daily wage from the north, In the eyes of everyone, he was "the Yankees". The terrible thing was that she desperately fell in love with him. She was looking forward to marrying Homer despite the intervention of the priest and dissuasion of her cousin. She had a great determination to pursue their love. But when Homer told her that he had no intention to get married, Emily had a huge psychological gap in her inner mind. Originally, she had bobbed hair, looked like a little girl and was about to begin a new life. Emily suffered such a big hit, it looked as if she must go back to her cage. And this time, it was not someone else's interference, but her beloved lover wanted to live up to herself. Stubborn character, because of it, Miss Emily eventually used the most extreme, cruel way to guard their love. To sum up, there was no doubt her character was responsible for her tragic fate and even it is the most convincible reason.

\section{Conclusion}

The short story of A Rose for Emily is aimed at more than only at conveying of one lady in the noble family-Emily's own tragedy from the birth to the death. William Faulkner is the dissector of crime, the describer of the dark times and the maker of the nightmare. All of his works has reflected the decline and corruption of the southern society after the Civil War.

When we lament for Emily in Faulkner's world, feel her helpless resistance and her woeful experience, we can, at the same time, profoundly appreciate the artistic charm in Faulkner's novel. Just as what Faulkner has said--this is an inevitable tragedy, which nothing can stop. Therefore, what Faulkner has revealed is not only the tragedy of a woman, but that of the human being. This is why this short story can be so vibrating.

\section{References}

[1] Kerr, Elizabeth M. Yoknapatawph: Faulkner's Little Post-age Stamp of Native Soil. New York: Fordham University. 1976.

[2] Olga Vickery. The Novels of William Faulkner: A Critical Appraisal. Baton Rouge: Louisiana State University Press. 1964.

[3] Swigart, Peter. The Art of Faulkner's Novel. University of Texas Press .Austin. (1962).

[4] Faulkner, A Rose for Emily[M].Translated by Taojie. Nanjing: Yilin Press, 2001 